\title{
KESALAHAN MAHASISWA DALAM MENYELESAIKAN \\ SOAL INTEGRAL BERDASARKAN GAYA KOGNITIF \\ PADA MATA KULIAH MATEMATIKA INFORMATIKA
}

(STUDENT'S ERRORS IN SOLVING INTEGRAL PROBLEMS BASED

ON THE COGNITIVE STYLE IN INFORMATICS MATH SUBJECT)

\author{
Ilham Rais Arvianto \\ STMIK Akakom Yogyakarta \\ ir.arvianto@akakom.ac.id
}

\begin{abstract}
Abstrak
Penelitian ini bertujuan untuk mendeskripsikan kesalahan mahasiswa dalam menyelesaikan soal matematika informatika materi integral berdasarkan gaya kognitif. Gaya kognitif dalam penelitian ini dikelompokkan menjadi gaya kognitif tipe field dependent (FD) dan tipe field independent (FI). Penelitian ini termasuk penelitian deskriptif dengan pendekatan kualitatif. Subjek penelitian terdiri dari 2 mahasiswa FD dan 2 mahasiswa FI. Subjek dipilih dengan teknik purposive sampling. Pengumpulan data menggunakan teknik tes dan wawancara. Uji keabsahan data menggunakan triangulasi teknik. Hasil penelitian menunjukkan bahwa jenis kesalahan dari mahasiswa FD adalah kesalahan konsep, operasi, dan prinsip. Sedangkan, mahasiswa FI hanya mengalami jenis kesalahan prinsip.
\end{abstract}

Kata kunci: Kesalahan Mahasiswa, Integral, Gaya Kognitif

\begin{abstract}
The aimed of this research to describe the student's errors in solving Informatics Maths subject in Integral Problems based of the cognitive style. In this research, cognitive style divided into field dependent (FD) and field independent (FI). This descriptive research used qualitative approach. Subjects of this research consisted of 2 FD students and 2 FI students. Subjects obtained by purposive sampling technique. Research data collected by test and interview. Test the validity of the data used technique triangulation. The results showed that the type of FD student's errors are misconception, operational error, and error on the principle, while FI student's error is only error on the principle.
\end{abstract}

Keywords: Student's Error, Integral, Cognitive Style 


\section{PENDAHULUAN}

Undang-undang Nomor 20 Tahun 2003 tentang Sistem Pendidikan Nasional menyebutkan bahwa pendidikan formal yaitu jalur pendidikan yang terdiri dari jenjang pendidikan dasar, pendidikan menengah, dan pendidikan tinggi. Matematika termasuk salah satu pengetahuan yang perlu dipelajari pada semua jenjang pendidikan formal tersebut. Menurut Abdurrahman (2010), alasan perlunya mempelajari matematika sebab matematika merupakan (1) sarana berpikir yang jelas dan logis, (2) sarana untuk memecahkan masalah kehidupan sehari-hari, (3) sarana mengenal pola-pola hubungan dan generalisasi pengalaman, (4) sarana untuk mengembangkan kreativitas, dan (5) sarana untuk meningkatkan kesadaran terhadap perkembangan budaya. Karena perannya yang sangat penting, sehingga matematika dipelajari sampai dengan jenjang pendidikan tinggi.

Bidang matematika juga dipelajari mahasiswa di Program Studi (Prodi) Teknik Informatika (TI) STMIK Akakom Yogyakarta. Di Prodi tersebut, salah satu mata kuliah rumpun matematika bernama Matematika Informatika, dengan bobot 3 sks. Pada kurikulum yang berlaku di STMIK Akakom Yogyakarta, mata kuliah ini ditempuh mahasiswa ketika semester dua. Dari silabi perkuliahan, kompetensi yang diharapkan tercapai dari mata kuliah ini adalah (1) mahasiswa mampu memahami konsep integral tertentu dan integral tak tentu serta penggunaannya untuk menghitung luasan dan volume benda putar, serta (2) mahasiwa mampu memahami konsep aljabar linear yang meliputi matriks, determinan dan invers matriks beserta penggunaannya pada penyelesaian sistem linear.

Secara umum, anggapan sebagian besar mahasiswa TI STMIK Akakom Yogyakarta bahwa materi pada mata kuliah matematika informatika termasuk dalam materi yang sulit untuk dipahami. Menurut penelitian Mutakin (2013), alasan yang menyebabkan mahasiswa TI kesulitan dalam memahami materi matematika adalah (1) anggapan mahasiswa bahwa materi matematika tidak ada hubungannya dengan Prodi TI, (2) mahasiswa kurang menyukai mata kuliah matematika, dan (3) kemampuan dasar kalkulus mahasiswa yang rendah. Alasanalasan tersebut mengindikasikan bahwa dari kondisi awal, mahasiswa TI memiliki kemampuan pemahaman konsep matematika yang rendah. Selain itu, persepsi dari mahasiswa TI yang cenderung menganggap matematika sulit dan tidak ada kaitannya dengan kompetensi perkuliahan di Prodi TI. Kondisi yang serupa juga terjadi pada mahasiswa di STMIK Akakom Yogyakarta.

Secara khusus, dari dua cakupan utama materi pada mata kuliah Matematika Informatika (integral dan aljabar linear), integral dianggap mahasiswa lebih sulit dipahami dibandingkan dengan aljabar linear. Ini didukung oleh data rata-rata nilai ujian matematika informatika pada tahun akademik 2015/2016 di Prodi TI. Dari 5 kelas Matematika Informatika (TI-1, TI-2, TI-3, TI-4, dan TI-5), diperoleh rata-rata nilai pada materi integral sebesar 53,46 , sedangkan pada materi aljabar linear mencapai 74,69. Nampak bahwa rata-rata nilai materi integral lebih rendah dari pada rata-rata nilai materi aljabar linear. Hal ini sungguh patut disesalkan, sebab sebagian besar materi integral telah mahasiswa pelajari di jenjang sekolah menengah atas. Pada jenjang pendidikan tinggi, perkuliahan hanya bersifat menyegarkan kembali, mengingat dan memperdalam materi. Akan 
tetapi, memang tidak dapat dipungkiri bahwa integral merupakan materi yang sulit untuk dipelajari (Purwati, Irawan, \& Rahardjo, 2013).

Penyelesaian soal integral membutuhkan pemahaman konsep yang baik, pemahaman rumus yang tepat, serta kejelian dan kreativitas yang tinggi. Proses yang kompleks ini menjadikan kesulitan tersendiri dalam mempelajari materi integral. Akibatnya, mahasiswa melakukan kesalahan dalam menyelesaikan soalsoal integral. Kesalahan-kesalahan ini perlu segera diidentifikasi melalui kegiatan analisis supaya tidak bedampak pada mata kuliah serumpun pada semestersemester berikutnya, seperti matematika diskrit dan metode numerik.

Secara umum, jenis integral terdiri dari integral biasa, integral subtitusi dan integral parsial. Karena keterbatasan waktu dan tenaga dari peneliti, kesalahan mengerjakan soal integral dalam penelitian ini dibatasi pada jenis integral biasa dan integral subtitusi. Selain itu, alasan lainnya adalah kedua jenis integral tersebut digunakan sebagai pokok dasar materi integral. Diharapkan jika kesalahan pada pokok dasar materi teridentifikasi melalui kegiatan analisis kesalahan, maka kesalahan pada materi integral selanjutnya (integral parsial) dapat diminimalisir.

Analisis kesalahan menurut Rahmania \& Rahmawati (2016) adalah penyelidikan terhadap suatu bentuk penyimpangan atau kekeliruan dari jawaban tertulis siswa. Oleh karena itu, kesalahan mahasiswa mengerjakan soal integral dapat diidentifikasi dari kekeliruan yang bersumber dari lembar jawab mahasiswa. Lebih lanjut, jenis kesalahan dapat dikelompokkan menjadi kesalahan konsep, operasi dan prinsip (Manibuy, Mardiyana, \& Saputro, 2014; Rahmania \& Rahmawati, 2016). Pengelompokan jenis kesalahan tersebut berkaitan dengan objek matematika. Mengadaptasi jenis kesalahan tersebut, dalam penelitian ini kesalahan yang dilakukan mahasiswa dalam menyelesaikan soal integral dikelompokkan dalam tiga jenis kesalahan, yaitu kesalahan konsep, kesalahan operasi dan kesalahan prinsip.

Kesalahan mengerjakan soal integral dari segi konsep, operasi, dan prinsip yang dialami setiap mahasiswa TI dimungkinkan tidak sama. Ada mahasiswa yang mengalami kesalahan pada suatu bagian dan bagian lainnya benar, tetapi ada juga yang sebaliknya. Walaupun secara umum kesalahan tersebut dipengaruhi dari sisi intelegensi mahasiswa, tetapi keberagaman karakteristik mahasiswa juga turut mempengaruhi. Terdapat berbagai faktor karakteristik mahasiswa yang berpengaruh terhadap hasil belajar mahasiswa. Menurut Slameto (Hikmawati, Kamid, \& Syamsurizal, 2013), salah satu faktor yang mempengaruhi hasil belajar matematika adalah faktor kognitif, yang meliputi aspek (1) persepsi (perseption), (2) perhatian (attention), (3) mendengarkan (listening), (4) ingatan (memory), (5) kesiapan (readiness), (6) struktur kognitif (cognitive structure), (7) inteligensi (intelligence), (8) kreativitas (creativity), dan (9) gaya kognitif (cognitive style).

Dari sembilan aspek tersebut, gaya kognitif merupakan salah satu aspek yang penting peranannya dalam mempengaruhi hasil belajar matematika. Menurut Usodo (2011), gaya kognitif adalah karakteristik individu dalam penggunaan fungsi kognitif (berpikir, mengingat, memecahkan masalah, membuat keputusan, mengorganisasi dan memproses informasi, dan seterusnya) yang bersifat konsisten dan berlangsung lama. Peninjauan kesalahan mengerjakan soal integral menurut aspek gaya kognitif ini penting dilakukan dalam pembelajaran matematika, sebab gaya kognitif sangat penting peranannya dalam meningkatkan kebermaknaan 
pembelajaran yang optimal terutama sekali dalam pembelajaran matematika (Hikmawati, Kamid, \& Syamsurizal, 2013). Selain itu, memperhatikan gaya kognitif mahasiswa akan memberikan hasil yang optimal terhadap pemahaman mahasiswa ketika proses pembelajaran (Nurafni, 2016). Oleh sebab itu, aspek gaya kognitif sangat penting diketahui guru/pengajar agar dapat memahami bahwa siswa/mahasiswa yang hadir dalam pembelajaran memiliki cara yang berbedabeda dalam menghadapi masalah atau tugas-tugas yang diberikan (Athira, Bennu, \& Rizal, 2015). Melihat urgensi perlunya memahami aspek gaya kognitif mahasiswa dalam meningkatkan kebermaknaan pembelajaran, meningkatkan pemahaman mahasiswa, serta memahami keberagaman mahasiswa dalam menghadapi tugas atau mengerjakan soal, maka peneliti tertarik untuk memfokuskan gaya kognitif sebagai sudut peninjauan dalam melakukan analisis kesalahan.

Menurut Slameto (Hikmawati, Kamid, \& Syamsurizal, 2013), salah satu tipe gaya kognitif yang telah dipelajari secara meluas adalah gaya field dependent (FD) dan gaya field independent (FI). Tinjauan tipe ini menekankan kepada perbedaan kondisi psikis cara analisis seseorang dalam berinteraksi dengan lingkungannya. Karakteristik gaya FD cenderung menerima suatu pola sebagai suatu keseluruhan dan mengalami kesulitan memisahkan aspek-aspek tertentu suatu situasi atau pola, sedangkan gaya FI lebih menunjukkan bagian-bagian terpisah dari pola menyeluruh dan mampu menganalisa pola ke dalam komponenkomponennya (Usodo, 2011). Lebih lanjut, menurut Hidayat, Sugiarto, \& Pramesti (2013), gaya FI cenderung kurang begitu tertarik dengan fenomena sosial, lebih suka dengan ide-ide dan prinsip-prinsip yang abstrak, kurang hangat dalam hubungan interpersonal, dan dalam mengerjakan tugasnya merasa efisien bekerja sendiri. Sementara itu, gaya FD dikategorikan sebagai seorang yang dapat berpikir secara global, berperilaku sensitive secara sosial dan berorientasi interpersonal, lebih suka bekerja kelompok dalam mengerjakan tugasnya.

Dari karakteristik-karakteristik tersebut dapat diartikan bahwa mahasiswa tipe FD cenderung memiliki pemikiran yang global (menerima pola sebagai suatu keseluruhan), kesulitan dalam hal analisis memisahkan aspek-aspek tertentu dan lebih suka bekerja kelompok dalam mengerjakan tugasnya. Sedangkan tipe FI cenderung memiliki karakteristik dapat menunjukkan bagian-bagian terpisah dari pola menyeluruh, mampu menganalisa pola ke dalam komponen-komponennya dan efisein mengerjakan tugasnya sendiri. Penjabaran tersebut menunjukkan adanya keterkaitan antara karakteristik masing-masing tipe gaya kognitif terhadap kesalahan mahasiswa dalam mengerjakan soal. Seseorang dengan gaya kognitif yang berbeda cenderung memiliki jenis kesalahan yang juga berbeda (Hidayat, Sugiarto, \& Pramesti, 2013). Dalam mengerjakan soal integral, mahasiswa bergaya FI cenderung melakukan analisis lebih tajam, sehingga dimungkinkan kesalahan yang dialami lebih sedikit. Sedangkan, mahasiswa bergaya FD akan cenderung mengerjakan soal sesuai dengan metode yang telah dipelajari atau diketahui sebelumnya, sehingga jika soal dimodifikasi sehingga berbeda signifikan dari soal yang telah mereka pelajari maka dimungkinkan mengalami kesalahan.

Berkaitan dengan uraian di atas, maka tujuan dari penelitian ini adalah untuk mendeskripsikan kesalahan mahasiswa dalam menyelesaikan soal matematika informatika materi integral berdasarkan gaya kognitif FD dan FI. 


\section{METODE}

Penelitian ini termasuk penelitian deskriptif dengan pendekatan kualitatif. Subjek penelitian dipilih dari mahasiswa kelas TI-5 STMIK Akakom Yogyakarta tahun akademik 2015/2016. Pemilihan subjek penelitian diawali dengan pemberian tes gaya kognitif GEFT (Group Embeded Figures Test) pada kelas tersebut untuk mengelompokkan mahasiswa menjadi kelompok FD dan FI. Kemudian dipilih tiga mahasiswa dari masing-masing kelompok gaya kognitif menggunakan teknik purposive sampling untuk menjadi subjek penelitian. Pemilihan subjek penelitian dilakukan berdasarkan informasi dari dosen pengampu mata kuliah, dengan kriteria (1) subjek memiliki kemampuan akademik sedang dan setara (berdasar data IPK mahasiswa), dan (2) subjek komunikatif dalam komunikasi secara tertulis maupun lisan. Dari proses tersebut, terpilih subjek FD-1 dan FD-2 (subjek tipe field dependent), serta FI-1 dan FI-2 (subjek tipe field independent).

Instrumen pengumpulan data dalam penelitian ini terdiri dari instrumen utama dan instrumen bantu. Instrumen utama adalah peneliti sendiri, sebab peneliti yang mengumpulkan data secara langsung. Instrumen bantu menggunakan soal tes gaya kognitif (GEFT), soal tes diagnostik dan pedoman wawancara. Soal tes diagnostik digunakan untuk mendeteksi jenis kesalahan yang dilakukan mahasiswa dalam mengerjakan soal integral. Instrumen ini berbentuk uraian yang terdiri dari soal tentang integral biasa dan integral subtitusi. Sebelum digunakan, instrumen ini telah divalidasi oleh validator, yakni dua dosen pengampu mata kuliah matematika informatika. Sementara itu, pedoman wawancara mengenai jenis kesalahan disusun sebagai pedoman untuk melakukan wawancara terhadap subjek dengan tujuan untuk mengklarifikasi jawaban tes tertulis yang telah diberikan dan untuk menggali data yang tidak terungkap dari hasil jawaban tes tertulis subjek penelitian.

Uji keabsahan (validitas) data penelitian ini menggunakan uji kredibilitas dengan teknik triangulasi teknik. Triangulasi teknik dilakukan dengan cara membandingkan data dari hasil tes diagnostik dan wawancara. Data dikatakan valid, jika terdapat kesesuaian data pada kedua teknik tersebut. Sementara itu, teknik analisis data dilakukan melalui tiga langkah, yaitu: (1) mentranskrip seluruh data penelitian dan melakukan reduksi data; (2) menyajikan data dalam bentuk teks naratif; kemudian (3) menyimpulkan kesalahan mengerjakan soal integral berdasar pada gaya kognitif.

\section{HASIL DAN PEMBAHASAN}

\section{Kesalahan Gaya Kognitif Field Dependent}

Dari hasil penelaahan lembar jawab dan wawancara, subjek FD-1 mengalami lima kesalahan. Kesalahan tersebut terletak pada (1) kesalahan mengintegralkan fungsi berpangkat negatif, (2) kesalahan mengintegralkan fungsi berbentuk pecahan, (3) kesalahan proses penurunan fungsi yang dimisalkan, (4) kesalahan mengubah bentuk hasil pemisalan menjadi bentuk yang dibutuhkan soal semula, dan (5) kesalahan subtitusi bentuk soal semula menjadi bentuk hasil pemisalan. Kesalahan yang dialami oleh subjek FD-1, dapat dilihat pada Gambar 1 berikut. 


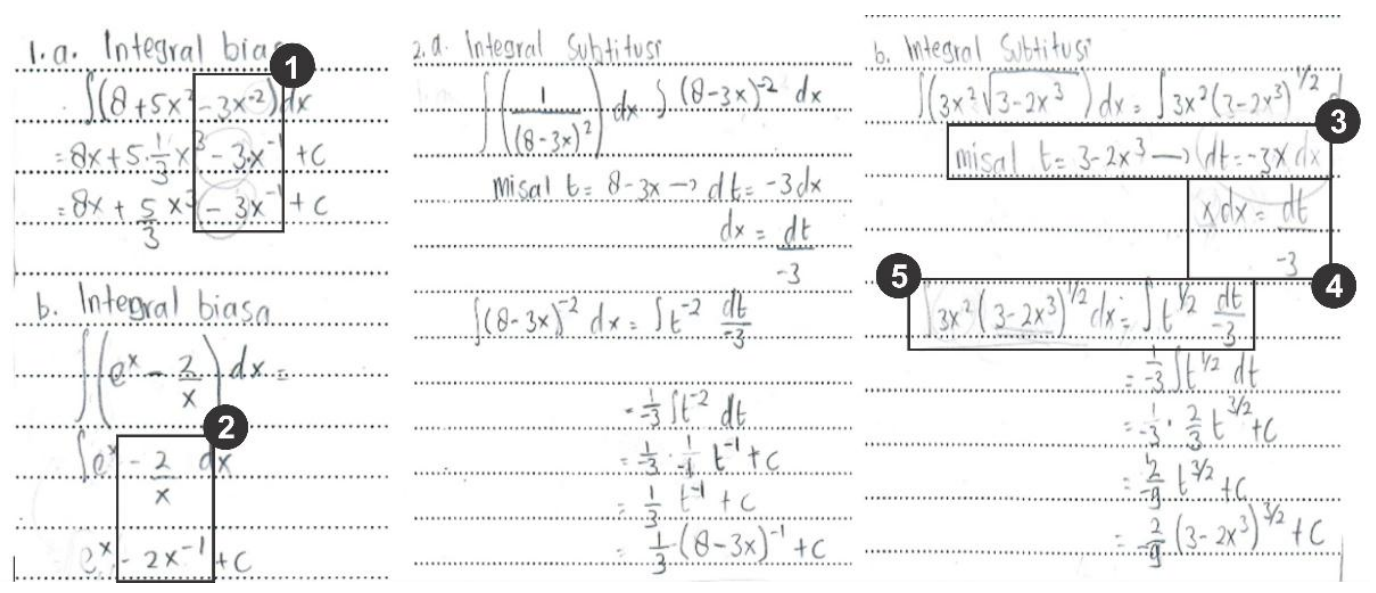

\section{Gambar 1. Kesalahan pada Subjek FD-1}

Sementara itu, pada subjek FD-2 ditemukan enam kesalahan. Letak kesalahan tersebut yaitu (1) kesalahan mengidentifikasi jenis soal integral, (2) kesalahan pemilihan suku yang dimisalkan, (3) kesalahan mengubah bentuk hasil pemisalan menjadi bentuk yang dibutuhkan soal semula, (4) kesalahan subtitusi bentuk soal semula menjadi bentuk hasil pemisalan, (5) kesalahan operasi perkalian, dan (6) kesalahan subtitusi balik hasil integrasi pemisalan menjadi bentuk soal semula. Kesalahan subjek FD-2 dapat dilihat pada Gambar 2 berikut.

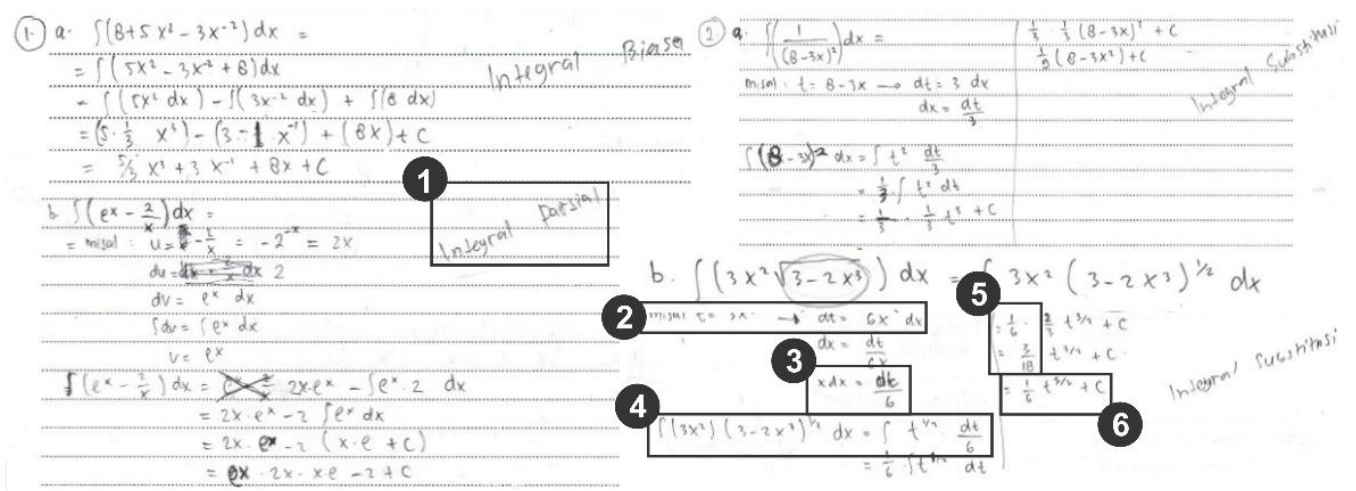

Gambar 2. Kesalahan pada Subjek FD-2

Dari kesalahan-kesalahan pada subjek FD-1 dan subjek FD-2 tersebut, maka secara umum subjek FD mengalami sembilan kesalahan mengerjakan soal integral yang terbagai menjadi kesalahan konsep, kesalahan prinsip, dan kesalahan operasi. Jenis kesalahan dan letak kesalahan subjek FD dalam mengerjakan soal integral dapat dilihat dalam Tabel 1 berikut.

Tabel 1. Kesalahan Mengerjakan Soal Integral Subjek FD

Jenis Kesalahan Letak Kesalahan Subjek FD
1. Konsep
a. Mengidentifikasi jenis soal integral
2. Operasi
a. Operasi perkalian yang melibatkan bentuk pecahan
3. Prinsip
a. Mengintegralkan fungsi berpangkat negatif
b. Mengintegralkan fungsi berbentuk pecahan
c. Pemilihan suku yang dimisalkan
d. Proses penurunan fungsi yang dimisalkan 
e. Mengubah bentuk hasil pemisalan menjadi bentuk yang dibutuhkan soal semula

f. Subtitusi bentuk soal semula menjadi bentuk hasil pemisalan

g. Subtitusi balik hasil integrasi pemisalan menjadi bentuk soal semula

Pada Tabel 1, terlihat bahwa kesalahan konsep dalam mengerjakan soal integral yang dialami gaya kognitif FD terletak pada kesalahan dalam mengidentifikasi jenis soal integral. Sementara itu, jenis kesalahan operasi terletak pada kesalahan operasi perkalian. Sedangkan, jenis kesalahan prinsip terletak pada kesalahan mengintegralkan fungsi berpangkat negatif, mengintegralkan fungsi berbentuk pecahan, pemilihan suku yang dimisalkan, proses penurunan fungsi yang dimisalkan, mengubah bentuk hasil pemisalan menjadi bentuk yang dibutuhkan soal semula, subtitusi bentuk soal semula menjadi bentuk hasil pemisalan, dan subtitusi balik hasil integrasi pemisalan menjadi bentuk soal semula.

\section{Kesalahan Gaya Kognitif Field Independent}

Dari hasil penelaahan lembar jawab dan wawancara, subjek FI-1 mengalami empat kesalahan. Kesalahan tersebut terletak pada (1) kesalahan mengintegralkan fungsi berpangkat negatif, (2) kesalahan proses penurunan fungsi yang dimisalkan, (3) kesalahan mengubah bentuk hasil pemisalan menjadi bentuk yang dibutuhkan soal semula, dan (4) kesalahan subtitusi bentuk soal semula menjadi bentuk hasil pemisalan. Kesalahan yang dialami oleh subjek FI-1, secara lebih lengkap dapat dilihat pada Gambar 3 berikut ini.

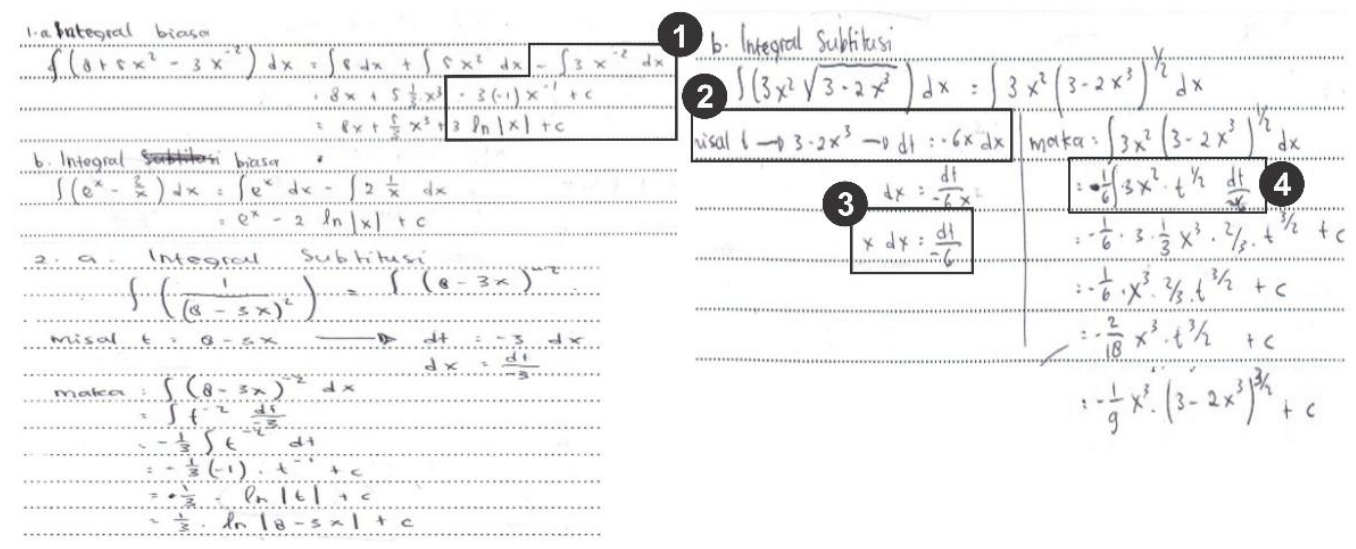

Gambar 3. Kesalahan pada Subjek FI-1

Sementara itu, pada penelaahan lembar jawab dan wawancara pada subjek FI-2 ditemukan bahwa dalam mengerjakan soal materi integral ditemukan empat kesalahan. Letak kesalahan tersebut, yaitu (1) kesalahan mengintegralkan fungsi berbentuk pecahan, (2) kesalahan proses penurunan fungsi yang dimisalkan, (3) kesalahan mengubah bentuk hasil pemisalan menjadi bentuk soal semula, dan (4) kesalahan subtitusi bentuk soal semula menjadi bentuk hasil pemisalan. Hasil pekerjaan beserta kesalahan yang dialami oleh subjek FI-2, secara lebih lengkap dapat dilihat pada Gambar 4. 

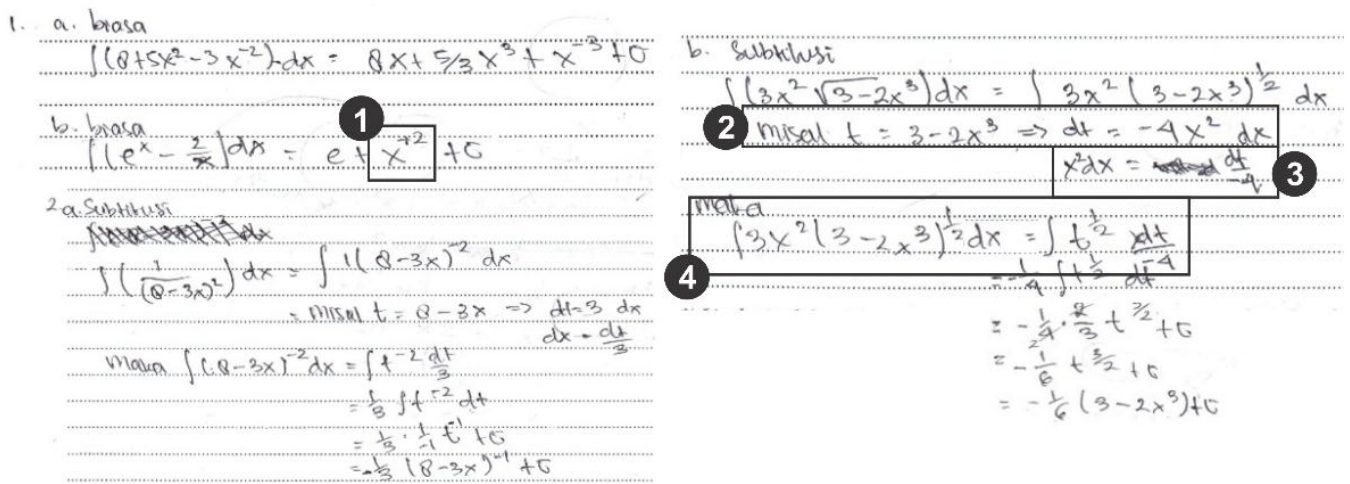

Gambar 4. Kesalahan pada Subjek FI-2

Dari kesalahan-kesalahan yang dialami oleh subjek FI-1 dan subjek FI-2 tersebut, maka secara umum subjek FI mengalami lima kesalahan mengerjakan soal integral. Jenis kesalahan dan letak kesalahan subjek FI dalam mengerjakan soal integral dapat dilihat dalam Tabel 2 berikut.

Tabel 2. Kesalahan Mengerjakan Soal Integral Subjek FI

\begin{tabular}{ll}
\hline \multicolumn{1}{c}{ Jenis Kesalahan } & \multicolumn{1}{c}{ Letak Kesalahan Subjek FI } \\
\hline 1. Konsep & - \\
2. Operasi & - \\
3. Prinsip & a. Mengintegralkan fungsi berpangkat negatif \\
& b. Mengintegralkan fungsi berbentuk pecahan \\
& c. Proses penurunan fungsi yang dimisalkan \\
& d. Mengubah bentuk hasil pemisalan menjadi bentuk soal semula \\
& e. Subtitusi bentuk soal semula menjadi bentuk hasil pemisalan \\
\hline
\end{tabular}

Pada Tabel 2, terlihat bahwa semua kesalahan dari subjek FI teridentifikasi sebagai kesalahan prinsip. Sementara itu, subjek FI tidak mengalami jenis kesalahan konsep dan kesalahan operasi. Hal ini menunjukkan bahwa subjek FI hanya mengalami jenis kesalahan prinsip.

\section{Persamaan dan Perbedaan Kesalahan Gaya Kognitif Field Dependent dan Field Independent}

Berdasarkan pada Tabel 1 dan Tabel 2 diketahui jenis kesalahan beserta letak kesalahan dari masing-masing gaya kognitif. Selanjutnya, peneliti mencoba melakukan analisis persamaan dan perbedaan dari kedua gaya kognitif tersebut. Adapun persamaan dan perbedaan kedua jenis kesalahan dan letaknya disajikan pada Tabel 3 berikut.

Tabel 3. Persamaan dan Perbedaan Kesalahan Mengerjakan Soal Integral Subjek FD dan Subjek FI

\begin{tabular}{ll}
$\begin{array}{c}\text { Jenis } \\
\text { Kesalahan }\end{array}$ & \multicolumn{1}{c}{$\begin{array}{c}\text { Persamaan dan Perbedaan } \\
\text { Letak Kesalahan Subjek FD dan Subjek FI }\end{array}$} \\
\hline 1. Konsep & a. Persamaan letak kesalahan kedua tipe gaya kognitif \\
& $\begin{array}{l}\text { b. } \text { Perbedaan letak kesalahan kedua tipe gaya kognitif } \\
\text { 1) Kesalahan subjek FD dalam mengidentifikasi jenis soal integral }\end{array}$ \\
& a. Persamaan letak kesalahan kedua tipe gaya kognitif
\end{tabular}


b. Perbedaan letak kesalahan kedua tipe gaya kognitif

1) Kesalahan subjek FD dalam operasi perkalian yang melibatkan bentuk pecahan

3. Prinsip a. Persamaan letak kesalahan kedua tipe gaya kognitif

1) Kesalahan mengintegralkan fungsi berpangkat negatif

2) Kesalahan mengintegralkan fungsi berbentuk pecahan

3) Kesalahan proses penurunan fungsi yang dimisalkan

4) Kesalahan mengubah bentuk hasil pemisalan menjadi bentuk yang dibutuhkan soal semula

5) Kesalahan subtitusi bentuk soal semula menjadi bentuk hasil pemisalan

b. Perbedaan letak kesalahan kedua tipe gaya kognitif

1) Kesalahan subjek FD dalam pemilihan suku yang dimisalkan

2) Kesalahan subjek FD dalam subtitusi balik hasil integrasi pemisalan menjadi bentuk soal semula

Pada Tabel 3, terlihat bahwa tidak terdapat persamaan kesalahan konsep yang dialami oleh kedua tipe gaya kognitif. Gaya kognitif FI tidak megalami jenis kesalahan konsep. Jenis kesalahan konsep hanya dialami oleh gaya kognitif FD. Kesalahan konsep dari gaya kognitif FD terletak pada kesalahan dalam mengidentifikasi jenis soal integral. Kesalahan konsep dalam materi integral teridentifikasi dari kekeliruan dalam mengklasifikasikan atau menggolong suatu soal ke dalam suatu jenis integral. Pada Gambar 2, terlihat bahwa soal yang semestinya diidentifikasi dan cukup dikerjakan dengan integral biasa, oleh subjek FD-2 diidentifikasi dan dikerjakan sebagai soal integral subtitusi. Dari hasil wawancara, diperoleh informasi bahwa alasan subjek FD-2 mengidentifikasi soal tersebut sebagai soal integral subtitusi karena berdasarkan pada intuisi dan pengalaman subjek ketika mengerjakan soal. Subjek mengasumsikan setiap soal yang memuat fungsi atau bilangan natural $(e)$ cenderung dikerjakan dengan prosedur integral subtitusi. Ini dikarenakan subjek FD kurang tepat dalam menganalisis suatu permasalahan. Hal ini mendukung pendapat Usodo (2011), bahwa subjek FD kesulitan untuk menganalisis pola menjadi bagian-bagian yang berbeda yang digunakan untuk menyelesaikan masalah. Selain itu, subjek bergaya kognitif FD menganggap suatu pola atau soal selalu bersifat global. Hal ini sejalan dengan kesimpulan Vendiagrys, Junaedi, \& Masrukan (2015), bahwa profil subjek FD dalam menyelesaikan masalah adalah lebih global dalam menerima informasi dan mudah terpengaruh manipulasi unsur pengecoh karena memandang secara global.

Pada jenis kesalahan operasi, terlihat bahwa tidak terdapat persamaan letak kesalahan operasi yang dialami oleh kedua tipe gaya kognitif. Subjek FI tidak mengalami kesalahan jenis ini. Hanya subjek FD yang mengalami jenis kesalahan operasi. Dilihat dari letak kesalahannya, subjek FD mengalami kesalahan dalam melakukan operasi perkalian yang melibatkan bentuk pecahan. Pada Gambar 2, terlihat subjek FD-2 menuliskan $\frac{1}{6} \cdot \frac{2}{3}=\frac{3}{18}$. Dalam mengerjakan operasi perkalian yang melibatkan pecahan, subjek hanya mengalikan unsur penyebut. Sementara untuk unsur pembilang dilakukan operasi penjumlahan. Dari hasil wawancara, diperoleh informasi bahwa subjek kurang teliti dalam melakukan operasi perkalian yang melibatkan bentuk pecahan. Hal ini mendukung pendapat Athira, 
Bennu, \& Rizal (2015), bahwa subjek dengan gaya kognitif FD kurang teliti dalam mencari hasil yang tepat.

Kesalahan jenis prinsip dalam materi integral mengandung arti kekeliruan dalam menggunakan aturan-aturan/rumus-rumus integral atau mengaitkan konsep integral dengan operasi yang ada di dalamnya. Pada kesalahan jenis ini, jika diamati dengan seksama terlihat bahwa terdapat persamaan dan perbedaan letak kesalahan yang dialami oleh kedua tipe gaya kognitif. Persamaan kesalahan menandakan kesalahan tersebut ditemukan pada gaya kognitif FD maupun FI. Persamaan kesalahan jenis prinsip yang dialami oleh kedua tipe gaya kognitif terletak pada lima tempat, yaitu (1) kesalahan mengintegralkan fungsi berpangkat negatif, (2) kesalahan mengintegralkan fungsi berbentuk pecahan, (3) kesalahan proses penurunan fungsi yang dimisalkan, (4) kesalahan mengubah bentuk hasil pemisalan menjadi bentuk yang dibutuhkan soal semula, dan (5) kesalahan subtitusi bentuk soal semula menjadi bentuk hasil pemisalan. Dari hasil wawancara, diperoleh informasi bahwa faktor utama yang menyebabkan kesalahan tersebut karena kemampuan dasar kalkulus dari subjek penelitian yang cukup rendah. Hal ini mendukung hasil penelitian Mutakin (2013) yang telah disebutkan di depan, yaitu salah satu alasan yang menyebabkan mahasiswa kesulitan dalam mempelajari materi matematika adalah kemampuan dasar kalkulus mahasiswa yang rendah.

Sementara itu, kesalahan jenis prinsip yang hanya dialami oleh subjek FD terletak pada dua tempat. Pertama, kesalahan subjek FD dalam pemilihan suku yang dimisalkan. Letak kesalahan ini dapat dilihat pada Gambar 2. Hasil wawancara menunjukkan bahwa subjek tidak memiliki alasan pasti dalam memilih suku yang dimisalkan. Tidak ada rencana yang disusun oleh subjek mengenai alasan dan akibat dari pemilihan suku tertentu. Hal ini mendukung pendapat Basir (2015) bahwa subjek FD lemah dalam menyusun rencana penyelesaian mengajukan dugaan sebagaimana tahapan memcahkan (solve) sehingga subjek kesulitan dalam penyelesaian masalah. Kedua, kesalahan subjek FD dalam subtitusi balik hasil integrasi pemisalan menjadi bentuk soal semula. Dari Gambar 2, terlihat bahwa subjek FD menuliskan hasil akhir jawabannya masih dalam bentuk pemisalan (variable $t$ ). Subjek tidak melakukan subtitusi balik dari variable $t$ menjadi variable $x$ sesuai dengan soal semula. Ini disebabkan karena subjek FD terburu-buru dalam mengerjakan soal dan tidak melakukan pemeriksaan kembali dari hasil jawabannya. Subjek FD berasumsi jawabannya sudah selesai pada langkah tersebut. Hal ini sejalan dengan kesimpulan Athira, Bennu, \& Rizal (2015), bahwa subjek FD kurang mampu melakukan pemeriksaan kembali hasil pekerjaannya.

\section{KESIMPULAN DAN SARAN}

Berdasarkan hasil penelitian dan pembahasan, maka dapat disimpulkan bahwa jenis kesalahan dalam menyelesaikan soal matematika informatika materi integral yaitu: (1) pada gaya kognitif FD, mengalami (a) kesalahan konsep, yang terletak pada kesalahan dalam mengidentifikasi jenis soal integral, (b) kesalahan operasi, yang terletak pada kesalahan subjek dalam operasi perkalian yang melibatkan bentuk pecahan, serta (c) kesalahan prinsip, yang terletak pada kesalahan mengintegralkan fungsi berpangkat negatif, kesalahan mengintegralkan fungsi berbentuk pecahan, kesalahan proses penurunan fungsi yang dimisalkan, 
kesalahan mengubah bentuk hasil pemisalan menjadi bentuk yang dibutuhkan soal semula, kesalahan subtitusi bentuk soal semula menjadi bentuk hasil pemisalan, kesalahan subjek FD dalam pemilihan suku yang dimisalkan, dan kesalahan subjek FD dalam subtitusi balik hasil integrasi pemisalan menjadi bentuk soal semula; dan (2) pada gaya kognitif FI hanya mengalami kesalahan prinsip, yang terletak pada kesalahan mengintegralkan fungsi berpangkat negatif, kesalahan mengintegralkan fungsi berbentuk pecahan, kesalahan proses penurunan fungsi yang dimisalkan, kesalahan mengubah bentuk hasil pemisalan menjadi bentuk yang dibutuhkan soal semula, dan kesalahan subtitusi bentuk soal semula menjadi bentuk hasil pemisalan.

Berdasarkan kesimpulan tersebut, maka saran yang peneliti berikan yaitu: (1) kepada dosen pengampu mata kuliah sebaiknya memperhatikan gaya kognitif mahasiswanya sehingga perkuliahan yang dilaksanakan sesuai dengan karakteristik dari mahasiswa, (2) kepada mahasiswa sebaiknya mengetahui gaya kognitifnya masing-masing agar dalam perkuliahan dapat menyesuaikan sehingga diperoleh hasil yang maksimal, dan (3) kepada peneliti selanjutnya sebaiknya mengembangkan penelitian lanjutan, misalnya mengembangkan model pembelajaran atau perangkat pembelajaran pada materi integral yang disesuaikan dengan gaya kognitif mahasiswa.

\section{DAFTAR RUJUKAN}

Abdurrahman, M. (2010). Pendidikan bagi anak berkesulitan belajar. Jakarta: PT. Rineka Cipta.

Athira, A. M., Bennu, S., \& Rizal, M. (2015). Analisis kemampuan siswa SMP di Kota Palu dalam memecahkan masalah segiempat berdasarkan gaya kognitif. Jurnal Sains dan Teknologi Tadulako, IV(1), 72-79.

Basir, M. A. (2015). Kemampuan penalaran siswa dalam pemecahan masalah matematis ditinjau dari gaya kognitif. Jurnal Pendidikan Matematika FKIP Unissula, III(1), 106-114.

Hidayat, B. R., Sugiarto, B., \& Pramesti, G. (2013). Analisis kesalahan siswa dalam menyelesaikan soal pada materi ruang dimensi tiga ditinjau dari gaya kognitif siswa. Jurnal Pendidikan Matematika Solusi, I(1), 39-46.

Hikmawati, Kamid, \& Syamsurizal. (2013). Pengaruh penggunaan media pembelajaran dan gaya kognitif terhadap hasil belajar matematika siswa kelas viii madrasah tsanawiyah. Tekno-Pedagogi, III(2), 1-11.

Manibuy, R., Mardiyana, \& Saputro, D. R. (2014). Analisis kesalahan siswa dalam menyelesaikan soal persamaan kuadrat berdasarkan taksonomi solo pada kelas x SMA Negeri Plus di Kabupaten Nabire - Papua. Jurnal Elektronik Pembelajaran Matematika, II(9), 933-945.

Mutakin, T. Z. (2013). Analisis kesulitan belajar Kalkulus 1 mahasiswa Teknik Informatika. Jurnal Formatif, III(1), 49-60.

Nurafni. (2016). Gaya kognitif field independent mahasiswa terhadap pemahaman konsep limit. Dalam Prosiding Seminar Nasional Matematika dan Pendidikan Matematika (SENATIK) I diselenggarakan pada 13 Agustus 2016 (h.230-239). Semarang: Prodi. Pend. Matematika FPMIPATI Universitas PGRI Semarang.

Purwati, E., Irawan, E. B., \& Rahardjo, S. (2013). Strategi ARIAS untuk meningkatkan pemahaman materi integral pada siswa talenta kelas xii 
SMA Negeri 2 Blitar. Dalam Prosiding Konferensi Nasional Pendidikan Matematika $V$ diselenggarakan pada 27-30 Juni 2013 (h.476-482). Malang: Himpunan Matematika Indonesia.

Rahmania, L., \& Rahmawati, A. (2016). Analisis kesalahan siswa dalam menyelesaikan soal cerita persamaan linier satu variabel. Jurnal Matematika dan Pendidikan Matematika, I(2), 165-174.

Usodo, B. (2011). Profil intuisi mahasiswa dalam memecahkan masalah matematika ditinjau dari gaya kognitif field dependent dan field independent. Dalam Prosiding Seminar Nasional Matematika dan Pendidikan Matematika UNS (h. 95-102). Surakarta: UNS.

Vendiagrys, L., Junaedi, I., \& Masrukan. (2015). Analisis kemampuan pemecahan masalaha matematika soal setipe timss berdasarkan gaya kognitif siswa pada pembelajaran model problem based learning. UJMER (Unnes Journal of Mathematics Education Research), IV(1), 34-41. 